\title{
Isotopic composition of nitrate and particulate organic matter in a pristine dam reservoir of western India: implications for biogeochemical processes
}

\author{
Pratirupa Bardhan, Syed Wajih Ahmad Naqvi, Supriya G. Karapurkar, Damodar M. Shenoy, Siby Kurian, and \\ Hema Naik \\ CSIR-National Institute of Oceanography, Dona Paula, Goa 403004, India
}

Correspondence to: Pratirupa Bardhan (pratirupabardhan@gmail.com)

Received: 6 July 2016 - Discussion started: 2 August 2016

Revised: 14 December 2016 - Accepted: 23 December 2016 - Published: 20 February 2017

\begin{abstract}
Isotopic composition of nitrate $\left(\delta^{15} \mathrm{~N}\right.$ and $\left.\delta^{18} \mathrm{O}\right)$ and particulate organic matter (POM; $\delta^{15} \mathrm{~N}$ and $\delta^{13} \mathrm{C}$ ) were measured in the Tillari Reservoir, located at the foothills of the Western Ghats, Maharashtra, western India. The reservoir, which is stratified during spring-summer and autumn seasons but gets vertically mixed during the southwest monsoon (SWM) and winter, is characterized by diverse redox nitrogen transformations in space and time. The $\delta^{15} \mathrm{~N}$ and $\delta^{18} \mathrm{O}$ values of nitrate were low $\left(\delta^{15} \mathrm{~N}=2-10 \%\right.$ o, $\delta^{18} \mathrm{O}=5-$ $8 \%$ ) during normoxic conditions but increased gradually (the highest at $\delta^{15} \mathrm{~N}=27 \%$ o, $\delta^{18} \mathrm{O}=29 \%$ ) when anoxic conditions facilitated denitrification in the hypolimnion during spring-early summer. Once nitrate was fully utilized and sulfidic conditions set in, $\mathrm{NH}_{4}^{+}$became the dominant inorganic $\mathrm{N}$ species, with $\delta^{15} \mathrm{~N}$ ranging from 1.3 to $2.6 \%$. Low $\delta^{15} \mathrm{~N}\left(\sim-5 \%\right.$ ) and $\delta^{13} \mathrm{C}(-37$ to $-32 \%$ ) of POM cooccurring with high $\mathrm{NH}_{4}^{+}$and $\mathrm{CH}_{4}$ in sulfidic bottom waters were probably the consequence of microbial chemosynthesis. Assimilation of nitrate in the epilimnion was the major controlling process on the $\mathrm{N}$ isotopic composition of POM $\left(\delta^{15} \mathrm{~N}=2-6 \%\right.$ ). Episodic low $\delta^{15} \mathrm{~N}$ values of POM ( -2 to $0 \%$ ) during early summer, coinciding with the absence of nitrate, might arise from $\mathrm{N}$ fixation, although further work is required to confirm the hypothesis. $\delta^{13} \mathrm{C} \mathrm{POM}$ in the photic zone ranged between -29 and $-27 \%$ o for most parts of the year. The periods of mixing were characterized by uniform $\delta^{15} \mathrm{~N}-\mathrm{NO}_{3}^{-}$and $\delta^{18} \mathrm{O}-\mathrm{NO}_{3}^{-}$at all depths. Higher POM (particulate organic carbon, POC, as well as particulate organic nitrogen, PON) contents and $\mathrm{C} / \mathrm{N}$ values with lower $\delta^{13} \mathrm{C}$ POM during the SWM point to allochthonous inputs. Over-
\end{abstract}

all, this study, the first of its kind in the Indian subcontinent, provides an insight into biogeochemistry of Indian reservoirs, using stable carbon and nitrogen isotopes as a tool, where the monsoons play an important role in controlling vertical mixing and dynamics of carbon and nutrients.

\section{Introduction}

Nitrogen is an essential macronutrient wherein the availability often limits primary production in aquatic ecosystems. It is a polyvalent element that undergoes redox transformation between the terminal oxidation states of +5 and -3 . These transformations involve isotopic fractionation to varying degrees, and therefore natural abundance of stable isotopes $\left({ }^{15} \mathrm{~N}\right.$ and $\left.{ }^{14} \mathrm{~N}\right)$ in various $\mathrm{N}$ species provides useful insight into nitrogen cycling besides its sources/sinks in the oceanic (Altabet, 1988; Sigman et al., 2005), coastal (Thunell et al., 2004; Hu et al., 2016) and estuarine (Cifuentes et al., 1988; Savoye et al., 2012) water bodies and sediments. Studies have also been undertaken in freshwater systems such as lakes (Pang and Nriagu, 1977; Chen et al., 2014) and reservoirs (Chen and Jia, 2009; Junet et al., 2009). Some of the best studied freshwater ecosystems in this regard are Lake Lugano at the Swiss-Italian border, Lake Kinneret in Israel and Lake Superior in the USA.

In the eutrophic Lake Lugano, the highly depleted $\delta^{13} \mathrm{C}$ and $\delta^{15} \mathrm{~N}$ of the near-bottom particulate organic matter (POM) established the active presence of methanotrophic bacteria during suboxic conditions (Lehmann et al., 2004). 
Seasonal changes in nitrogen species were reflected in the isotopic composition of POM and dissolved inorganic nitrogen (DIN) compounds in Lake Kinneret (Hadas et al., 2009). Various processes like nitrification, denitrification and $\mathrm{N}_{2}$ fixation were identified with the help of the $\mathrm{N}$ isotopes. In Lake Superior, based on nitrate isotopic studies it was possible to identify the increasing inputs of reduced $\mathrm{N}$ to the lake and its subsequent nitrification to be the cause behind a century-long increase in the nitrate inventory of the lake, ruling out atmospheric deposition as the other probable cause (Finlay et al., 2007).

There are a large number of natural freshwater lakes as well as man-made reservoirs in India. In fact, India has the third-highest number of dams (around 4300) in the world, after China and USA. However, these systems have not been well investigated for biogeochemical cycling. In the very first study of its kind, Narvenkar et al. (2013) sampled eight dam reservoirs spread across India and observed strong thermal stratification during summer in all reservoirs. Six of these reservoirs were found to experience varying degrees of oxygen depletion in the hypolimnia, ranging from hypoxia to complete anoxia, in spring-summer. Anoxia has been found to greatly affect the distribution of nitrogen species in these systems. In order to gain insights into biogeochemical cycling in these poorly investigated water bodies, we selected the Tillari Reservoir for detailed studies. These included measurements of natural abundance of nitrogen and oxygen isotopes in nitrate, and nitrogen and carbon isotopes in POM. These data, first of their kind generated from any Indian freshwater body, facilitate an understanding of biogeochemical processes (especially involving nitrogen) that should be typical of any relatively pristine, tropical, monsoon-affected freshwater body.

\section{Methods}

\subsection{Site description}

The Tillari Reservoir is situated in the Dodamarg taluka in the Sindhudurg district of Maharashtra $\left(15^{\circ} 76^{\prime} \mathrm{N}, 74^{\circ} 12^{\prime} \mathrm{E}\right.$; Fig. 1). Created by damming the Tillari River, the reservoir has a maximum depth of $\sim 50 \mathrm{~m}$ and a storage capacity of $0.45 \times 10^{9} \mathrm{~m}^{3}$ (Kurian et al., 2012). The reservoir is located close to the foothills of the Western Ghats, with the drainage basin having evergreen forests (C3 plant type) as well as grasslands (C3 or C4 plant types) (Sukumar et al., 1995). The drainage basin of Tillari has a low population density, and therefore the river water is not much impacted by human activities such as municipal and industrial discharges, and agriculture. This is reflected by high water quality (Shenoy et al., 2017). The region receives rainfall averaging around $3000 \mathrm{~mm}$ annually, almost entirely between June and September. The evaporation rate in the Tillari Reservoir is not known, but for other Indian reservoirs the evaporative loss is reported to average around $0.2 \mathrm{~m}$ (Subramanya, 2013) per month. Water from the Tillari Reservoir is mainly used for irrigation. Some watershed characteristics of the Tillari Reservoir have been listed in Table S1 in the Supplement.

The Tillari Reservoir is a dimictic water body. Relatively low air temperatures and cool winds descending from the Western Ghats, located immediately to the east of the reservoir, result in convective mixing and well-oxygenated conditions in winter. The water column gets thermally stratified in spring and remains this way until the strong southwest monsoon (SWM) winds and supply of relatively cold water homogenize the water column again. The water column gets stratified after the SWM. Stratification during springsummer leads to an anoxic condition that is most intense (sulfidic in most years) just before the onset of mixing in JuneJuly. A previous study (Kurian et al., 2012) showed that the occurrence of sulfidic conditions within the euphotic zone supports anoxygenic photosynthesis with brown sulfur bacteria in this reservoir. Methane has been found to accumulate in high concentrations below the thermocline during this period; however, its emissions into the atmosphere are not very high (Narvenkar et al., 2013). Direct human impacts on nutrient inventory of the reservoir are relatively minor, as the basin is located amidst thick forests with low human population density and minimum agricultural activities.

\subsection{Sampling and field measurements}

Sampling was conducted at one station located at the deepest part of the reservoir. Water samples from pre-fixed depths were collected with $5 \mathrm{~L}$ Niskin samplers attached to nylon ropes and equipped with reversing thermometers to measure temperature. Subsamples for dissolved oxygen (DO) and hydrogen sulfide $\left(\mathrm{H}_{2} \mathrm{~S}\right)$ were collected carefully avoiding air exchange. Subsamples for nutrients (nitrate and ammonium) were collected in clean $60 \mathrm{~mL}$ HDPE bottles and frozen immediately. Subsamples for stable isotopic analyses were collected in $5 \mathrm{~L}$ acid-cleaned plastic carboys and transported to the laboratory within 3-4h.

\subsection{Laboratory analyses}

Dissolved $\mathrm{O}_{2}$ was estimated with the Winkler method (Grasshoff et al., 1983) with a precision of $<1 \mu \mathrm{M}$. $\mathrm{NO}_{3}^{-}$and $\mathrm{NH}_{4}^{+}$were measured using a SKALAR segmented flow analyser following standard procedures (Grasshoff et al., 1983) with a precision of $<0.1 \mu \mathrm{M}$. Dissolved $\mathrm{H}_{2} \mathrm{~S}$ concentration was determined colorimetrically (Cline, 1969).

\subsection{Isotopic analyses}

Sampling for isotopic analyses of POM commenced in March 2010 and continued on a monthly basis till 2012. From 2012 to 2015 samples were collected on a seasonal basis. Samples for nitrate isotopic measurements were collected from 2011. The facility for nitrate isotope analysis was 


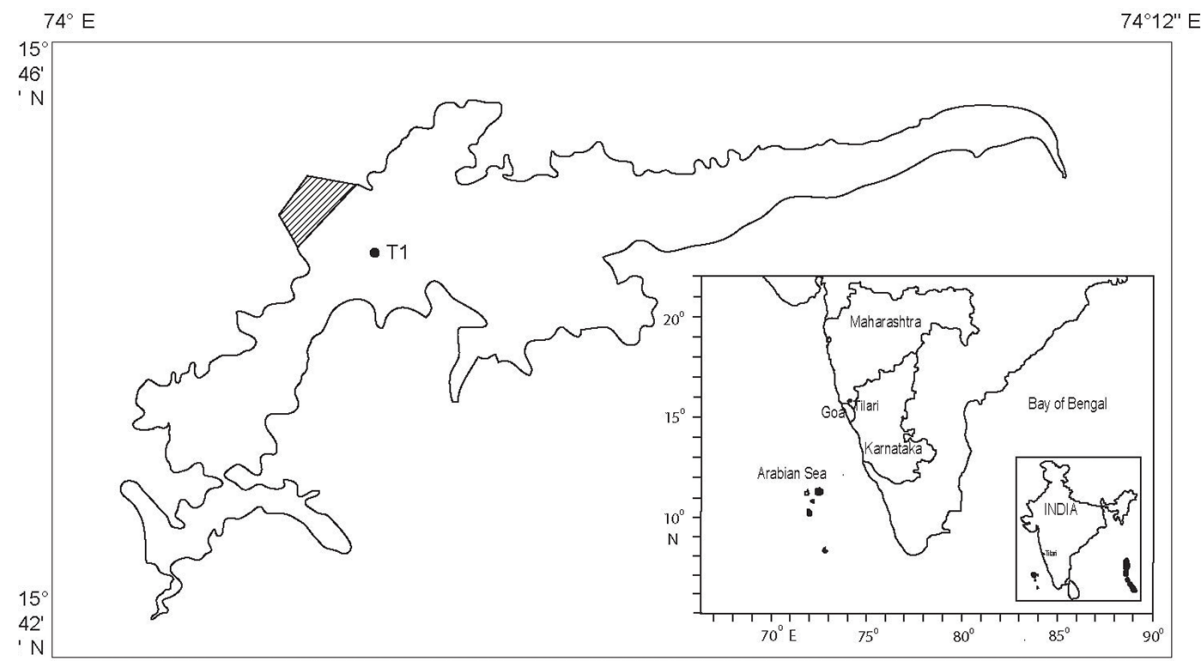

Figure 1. Map of the sampling location (Tillari Reservoir). T1 shows the main sampling location at the deepest point of the reservoir.

created in 2014 and samples from 2014 and 2015 were analysed immediately for natural abundance of $\mathrm{N}$ and $\mathrm{O}$ isotopes. Samples from 2011 and 2012 were also analysed on a selective basis. Samples (up to $3 \mathrm{~L}$ ) for isotopic analyses of POM and DIN (dissolved inorganic nitrogen; i.e. $\mathrm{NO}_{3}^{-}$and $\mathrm{NH}_{4}^{+}$) were filtered through precombusted $\left(450^{\circ} \mathrm{C}\right.$ for $\left.4 \mathrm{~h}\right) 47 \mathrm{~mm}$ $\mathrm{GF} / \mathrm{F}$ filters (pore size $=0.7 \mu \mathrm{m}$ ). The filtrate was used for DIN isotopic measurements and the filter papers were placed in petriplates and frozen immediately.

\subsubsection{Analyses of $\delta^{15} \mathrm{~N}$ and $\delta^{18} \mathrm{O}$ of $\mathrm{NO}_{3}^{-}$}

Samples for isotopic analysis of nitrate were preserved in two ways. While samples collected in 2011 and 2012 were acidified with $\mathrm{HCl}$ to $\mathrm{pH} 2.5$, those taken in 2014 and 2015 were frozen immediately and analysed within a week. Prior to the isotopic analyses, nitrate and nitrite concentrations were measured colorimetrically. Isotopic analyses of nitrogen and oxygen in $\mathrm{NO}_{3}^{-}$were carried out following the "chemical method" (McIlvin and Altabet, 2005) involving reduction of $\mathrm{NO}_{3}^{-}$to $\mathrm{NO}_{2}^{-}$by cadmium and further reduction to $\mathrm{N}_{2} \mathrm{O}$ by sodium azide in an acetic acid buffer. The resulting $\mathrm{N}_{2} \mathrm{O}$ gas in the headspace was purged into a GasBench II (Thermo Finnigan) and analysed in a Delta $\mathrm{V}$ isotope ratio mass spectrometer.

Nitrite concentration was insignificant in most of the samples; sulfamic acid was added in a few samples that contained nitrite in concentrations exceeding $0.1 \mu \mathrm{M}$. Working standards were prepared in low-nutrient surface seawater (LNSW) collected from the Arabian Sea. Calibration was done using the international nitrate isotope standards USGS32, USGS-34 and USGS-35. For further quality assurance, an internal potassium nitrate standard (spanning the range of nitrate concentration in the samples) was run with each batch of samples. Magnesium oxide (MgO; Fisher, precombusted for $4 \mathrm{~h}$ at $450^{\circ} \mathrm{C}$ ) was added to each sample to raise the $\mathrm{pH}$ close to 9 , which was followed by addition of cadmium. We used cadmium powder (Alfa Aesar, -325 mesh, 99.5\%) instead of spongy cadmium as mentioned in McIlvin and Altabet (2005). Each vial was wrapped in aluminium foil and placed on a horizontal shaker at low speed for $17 \mathrm{~h}$. After the stipulated time, samples were removed from the shaker, centrifuged and decanted into clean vials. The nitrite concentrations in the decanted samples were measured to check the extent of reduction.

Sodium azide (2M solution) and $20 \%$ acetic acid were mixed in $1: 1$ proportion (by volume) to yield the azideacetic acid buffer (A-AA buffer) solution. In $20 \mathrm{~mL}$ crimp vials, samples and standards were diluted with LNSW for a final concentration of 20 nanomoles and a final volume of $15 \mathrm{~mL}$. Two international nitrite standards (N23 and N20) were added in this step to check the efficiency of $\mathrm{N}_{2} \mathrm{O}$ production by the buffer. After the addition of the A-AA buffer, the vials were allowed to stand for $1 \mathrm{~h}$ and then the reaction was stopped by adding $0.5 \mathrm{~mL}$ of $10 \mathrm{M} \mathrm{NaOH}$.

The "chemical" method yielded a very low blank $(\sim 0.5 \mu \mathrm{M})$ and worked well for the low concentration samples. The international standards were run before and after each batch of samples, while the internal nitrate standards were run after every five samples. Analytical precision (1 standard deviation) was better than $0.3 \%$ for $\delta^{15} \mathrm{~N}$ and better than $0.7 \%$ o for $\delta^{18} \mathrm{O}$. Results are expressed in $\delta$ notation $\left(\delta^{15} \mathrm{~N}\right.$ and $\left.\delta^{18} \mathrm{O}\right)$, as per mil $(\% \circ)$ deviation from atmospheric nitrogen and Vienna Standard Mean Ocean Water, respectively.

\subsubsection{Analyses of $\delta^{15} \mathrm{~N}$ of $\mathrm{NH}_{4}^{+}$}

Samples for measurements of $\delta^{15} \mathrm{~N}-\mathrm{NH}_{4}^{+}$were collected during May 2012 from the anaerobic hypolimnetic waters. 
The $\delta^{15} \mathrm{~N}$ of $\mathrm{NH}_{4}^{+}$was measured by the "ammonia diffusion" method (Holmes et al., 1998). Briefly, $500 \mathrm{~mL}$ of the sample was collected in duplicates to which $1.5 \mathrm{~g}$ of $\mathrm{MgO}$ was added to elevate the $\mathrm{pH}$. The diffused $\mathrm{NH}_{4}^{+}$was trapped onto an acidified glass-fiber filter sealed between two porous Teflon membranes. The sample bottles were kept in an incubator shaker $\left(20^{\circ} \mathrm{C}, 80 \mathrm{rpm}\right)$ for 2 weeks for complete diffusion of $\mathrm{NH}_{4}^{+}$. After 2 weeks, the GF filters were removed from each sample, dried in a $\mathrm{NH}_{4}^{+}$-free environment, packed into tin cups and immediately analysed using CF-EA-IRMS (continuous flow elemental analysis isotope ratio mass spectrometry). Results were corrected for blank, percent recovery and fractionation. Analytical precision was better than $0.6 \%$.

\subsubsection{Analyses of $\delta^{13} \mathrm{C}$ and $\delta^{15} \mathrm{~N}$ of POM and surface sediment}

The analyses of $\delta^{13} \mathrm{C}$ and $\delta^{15} \mathrm{~N}$ of POM were usually conducted within 1-2 months of collection. The frozen filters were acid fumed with $36 \% \mathrm{HCl}$ to eliminate carbonates and air dried in a clean laminar flow. Two aliquots (each of $12 \mathrm{~mm}$ diameter) were sub-sectioned from each filter and packed into tin cups for analysis. Detailed methodology is given in Maya et al. (2011). The $\delta^{13} \mathrm{C}$ and $\delta^{15} \mathrm{~N}$ of POM along with particulate $\mathrm{C}$ and $\mathrm{N}$ contents were analysed in the same sample using a stable isotope ratio mass spectrometer (Thermo Finnigan Delta V) connected to an elemental analyser (EURO3000 Eurovector). Results are expressed as per mil $(\%)$ deviation with respect to Pee Dee Belemnite (PDB) for $\delta^{13} \mathrm{C}$ and atmospheric nitrogen for $\delta^{15} \mathrm{~N}$. Analytical precision was better than $\pm 0.2 \%$ as determined from repeated measurements (after every five samples) of a working standard, $\varepsilon$-amino-n-caproic acid having $\delta^{13} \mathrm{C}=-25.3 \% o$ and $\delta^{15} \mathrm{~N}=4.6 \%$ o, and a laboratory sediment standard having $\delta^{13} \mathrm{C}=-21 \%$ and $\delta^{15} \mathrm{~N}=7.5 \%$.

Surface sediment collected from the reservoir during the May 2012 field trip was analysed on only one occasion to investigate its role as an ammonium source. The freeze-dried, homogenized sample was analysed following similar protocol.

\section{Results}

\subsection{Water-column observations}

Based on the vertical temperature distribution it appears that the reservoir gets vertically mixed through convective overturning in winter (December to February, with the exact duration of mixing depending upon meteorological conditions prevailing in a given year). In spring, stratification sets in and is the most intense from April to June/July (with a surfaceto-bottom temperature difference of $7-8{ }^{\circ} \mathrm{C}$ ). The water column is again homogenized following SWM-induced mixing and flow of relatively cold water, followed by weaker stratification in autumn-early winter. A detailed discussion on the physico-chemical parameters is provided in Shenoy et al. (2017).

The epilimnion was always oxic. During the stratification periods, the DO concentrations dropped rapidly within the thermocline. The water column became well-oxygenated following the onset of the SWM. $\mathrm{H}_{2} \mathrm{~S}$ was detected below $20 \mathrm{~m}$ during the period of intense stratification (Kurian et al., 2012), with the highest concentration recorded being $9.88 \mu \mathrm{M}$. The occurrence of $\mathrm{H}_{2} \mathrm{~S}$ was accompanied by the appearance of $\mathrm{CH}_{4}$ and $\mathrm{NH}_{4}^{+}$. Up to $160 \mu \mathrm{M}$ of $\mathrm{CH}_{4}$ and $30 \mu \mathrm{M}$ of $\mathrm{NH}_{4}^{+}$were observed in the anoxic bottom waters during peak summer (Narvenkar et al., 2013) (Fig. 6).

A thorough analysis of nutrient dynamics in the Tillari Reservoir is provided by Naik et al. (2017). Here we provide a brief description of nitrate profiles during the study period. Surface-water nitrate concentrations were typically low throughout the year ranging from below detection limit to $0.7 \mu \mathrm{M}$. However, the surface nitrate concentrations were as high as $\sim 10 \mu \mathrm{M}$ (Fig. 3a) during the SWM. Nitrate concentrations gradually increased below the epilimnion during the period of weak stratification. However, with the depletion of DO, nitrate concentrations in the hypolimnion decreased from $3.6 \mu \mathrm{M}$ (at $20 \mathrm{~m}$ ) to $0.3 \mu \mathrm{M}$ (at $35 \mathrm{~m}$ ), indicating $\mathrm{N}$ loss. Re-oxygenation of hypolimnion during the SWM was accompanied by increase in nitrate concentrations $(5-10 \mu \mathrm{M})$.

\subsection{Isotopic composition of nitrate and ammonium}

Large variations in the isotopic composition of nitrate and ammonium were observed in space and time. Isotopic composition of nitrate in the epilimnion could not be measured on several occasions due to low concentrations. However, when the measurements could be made it was observed that the $\delta^{15} \mathrm{~N}$ and $\delta^{18} \mathrm{O}$ values of epilimnetic $(0-10 \mathrm{~m}) \mathrm{NO}_{3}^{-}$were high $\left(\delta^{15} \mathrm{~N}=8-25 \%\right.$ o, $\delta^{18} \mathrm{O}=24-29 \%$ ) (Fig. 3b) during the summer stratification presumably due to autotrophic assimilation, whereas relatively lower values $\left(\delta^{15} \mathrm{~N}=5-8 \%\right.$, $\delta^{18} \mathrm{O}=12-15 \%$ ) were observed during the monsoon mixing events. Increasing $\delta^{15} \mathrm{~N}$ and $\delta^{18} \mathrm{O}$ of $\mathrm{NO}_{3}^{-}$, coupled to decreasing $\left[\mathrm{NO}_{3}^{-}\right]$, were also observed in the suboxic hypolimnion during April and May, when the water column was strongly stratified. The highest $\delta^{15} \mathrm{~N}$ values observed were $27.7 \%$ (in 2014) and $22.4 \%$ (in 2012) while the corresponding highest $\delta^{18} \mathrm{O}$ values were 29.5 and $28.8 \%$, respectively.

The water column remains weakly stratified for a large part of the year, usually from October to March. A trend of increasing concentrations of isotopically light $\left(\delta^{15} \mathrm{~N}=2-8 \%\right.$ o and $\delta^{18} \mathrm{O}=5-8 \%$ ) nitrate was observed in the hypolimnion along with gradually decreasing levels of oxygen and ammonium implying the occurrence of nitrification. As the stratification intensified, this phenomenon was restricted only to the metalimnion. After nitrate was exhausted, high ammonium build-up was observed in the bottom waters. In May 2012, $\mathrm{NH}_{4}^{+}$concentrations increased from $0.6 \mu \mathrm{M}$ at $20 \mathrm{~m}$ to nearly 
$12 \mu \mathrm{M}$ at $40 \mathrm{~m}$ with a corresponding decrease in $\delta^{15} \mathrm{~N}-\mathrm{NH}_{4}^{+}$ from $2.6 \%$ at $20 \mathrm{~m}$ to $1.3 \%$ at $40 \mathrm{~m}$ (Fig. $5 \mathrm{a}$ ).

Elevated nitrate concentrations occur throughout the water column during the SWM. The $\delta^{15} \mathrm{~N}$ and $\delta^{18} \mathrm{O}$ of $\mathrm{NO}_{3}^{-}$showed little vertical variations at this time. However, inter-annual variability was seen in the $\delta^{15} \mathrm{~N}$ of nitrate $(3.94 \pm 2.4 \%$ in $2011,11.38 \pm 1.6 \%$ in 2014 and $5.47 \pm 1.8 \%$ in 2015), the cause of which will be examined. By contrast, the $\delta^{18} \mathrm{O}-\mathrm{NO}_{3}^{-}$values were relatively less variable $(13.01 \pm 4.8 \%$ in $2011,15.41 \pm 2.3 \%$ in 2014 and $12.46 \pm 4.9 \%$ in 2015$)$.

\subsection{Isotopic and elemental composition of suspended particulate organic matter}

The suspended particulate organic matter in the Tillari Reservoir showed distinct seasonal and depth-wise variations in its isotopic and elemental compositions (Fig. 2). Primary productivity in the epilimnion led to higher $\delta^{15} \mathrm{~N}$ (2 to $6 \%$ ) and $\delta^{13} \mathrm{C}(-28$ to $-26 \%$ ) in POM and higher particulate organic carbon (POC; 35-60 $\mu \mathrm{M}$ ) and particulate organic nitrogen (PON; 4-6 $\mu \mathrm{M}$ ) contents as compared to the bottom water. The molar $\mathrm{C} / \mathrm{N}$ ratios in the surface waters ranged between 7 and 10. Depleted $\delta^{15} \mathrm{~N}(\sim-1.4 \%)$ in the epilimnion was observed during the early stratification period (February and March). As the stratification intensified, the $\delta^{15} \mathrm{~N}$ and $\delta^{13} \mathrm{C}$ of the epilimnetic POM became heavier, presumably reflecting a gradual enrichment of heavier isotopes in the dissolved inorganic $\mathrm{N}$ and $\mathrm{C}$ pools. Both $\delta^{15} \mathrm{~N}$ and $\delta^{13} \mathrm{C}$ decreased with depth with the lowest values occurring in the anoxic bottom water during the peak stratification period. The $\mathrm{C} / \mathrm{N}$ values in these waters were in the range of 4-7. In terms of seasonal variability, $\delta^{13} \mathrm{C}$ values of POM were lower during monsoon mixing and became more enriched as the stratification intensified. The $\delta^{15} \mathrm{~N}$ values, however, did not depict any distinct seasonal pattern. High POC (up to $80 \mu \mathrm{M}$ ) and PON (up to $9 \mu \mathrm{M})$ along with high $\mathrm{C} / \mathrm{N}(>10)$ were recorded during the monsoon season apparently reflecting allochthonous inputs.

\section{Discussion}

\subsection{Epilimnetic processes}

Nitrate concentrations in surface waters of the Tillari Reservoir varied from below detection limit during the premonsoon period to $10.7 \mu \mathrm{M}$ during the SWM. The $\delta^{18} \mathrm{O}$ and $\delta^{15} \mathrm{~N}$ values of nitrate in the epilimnion were high, a signature of assimilation: phytoplankton prefer nitrate containing ${ }^{14} \mathrm{~N}$ and ${ }^{16} \mathrm{O}$ leaving residual nitrate enriched with $\delta^{15} \mathrm{~N}$ and $\delta^{18} \mathrm{O}$ (Casciotti et al., 2002). We examined the slopes of the $\delta^{18} \mathrm{O}$ vs. $\delta^{15} \mathrm{~N}$ regression in the surface water. While a $1: 1$ line would represent assimilation of epilimnetic nitrate, a steeper slope would imply assimilation along with the regeneration of nitrate via nitrification (Wankel et al., 2007). We observed a nearly $1: 1$ trend for most of the surface-water

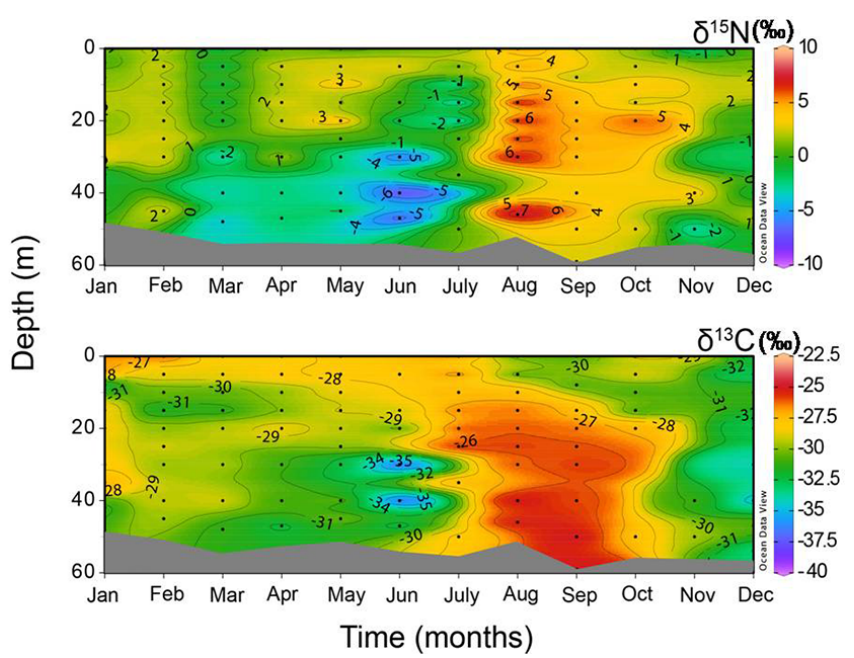

Figure 2. Mean annual variations of $\delta^{15} \mathrm{~N}$ POM and $\delta^{13} \mathrm{C}$ POM at the main sampling location.

samples during the summer stratification implying that assimilation exerts a major control on surface $\mathrm{NO}_{3}^{-}$isotopic composition (Fig. S1 in the Supplement).

The isotopic composition of the DIN source exerts the key control on the $\delta^{15} \mathrm{~N}$ of POM (Altabet, 2006). The epilimnetic POM in the Tillari Reservoir is expected to have $\delta^{15} \mathrm{~N}$ less than or equal to the $\delta^{15} \mathrm{~N}-\mathrm{NO}_{3}^{-}$. Indeed, the $\delta^{15} \mathrm{~N}$ POM was always lower than the $\delta^{15} \mathrm{~N}$ of the source nitrate (Fig. 3b). The range of $\delta^{13} \mathrm{C}$ values of surface-water POM $(-32$ to $-26 \%$ o) was typical of lacustrine autochthonous organic matter ( -42 to $-24 \%$; Kendall et al., 2001, and references therein). As the summer progressed, productivity increased resulting in increased $\mathrm{CO}_{2}$ uptake and elevated $\delta^{13} \mathrm{C}$ POM. During photosynthesis, phytoplankton have a preferential uptake of ${ }^{12} \mathrm{C}$ leaving the dissolved inorganic carbon (DIC) pool enriched in ${ }^{13} \mathrm{C}$. However, when dissolved $\mathrm{C}$ is scarce and/or growth rate is high, the phytoplankton would consume the available DIC with reduced or no isotopic discrimination. As the summer progressed at the study location, increased water temperature and low dissolved inorganic nutrient and DIC concentrations would cause the phytoplankton to express reduced isotopic discrimination. This would result in enriched $\delta^{13} \mathrm{C}$ POM. Similar enrichment of $\delta^{13} \mathrm{C}$ POM during periods of high productivity have also been observed in other lakes, e.g. Lake Lugano (Lehmann et al., 2004) and Lake Wauberg (Gu et al., 2006).

In March, when nitrate was close to the detection limit, surface $\delta^{15} \mathrm{~N}$ POM was $-1.4 \%$. The POM resulting from nitrogen fixation by cyanobacteria usually has a $\delta^{15} \mathrm{~N}$ of 0 to $-2 \%$ o (Carpenter et al., 1997). Zeaxanthin, marker pigment of cyanobacteria, was present in significant concentrations $\left(305.1 \pm 21 \mathrm{ng} \mathrm{L}^{-1}\right)$ within the epilimnion, whereas Chl $a$ concentration was $\sim 1.7 \mu \mathrm{gL}^{-1}$ (S. Kurian, unpublished data). However, measurements of nitrogen fixation 

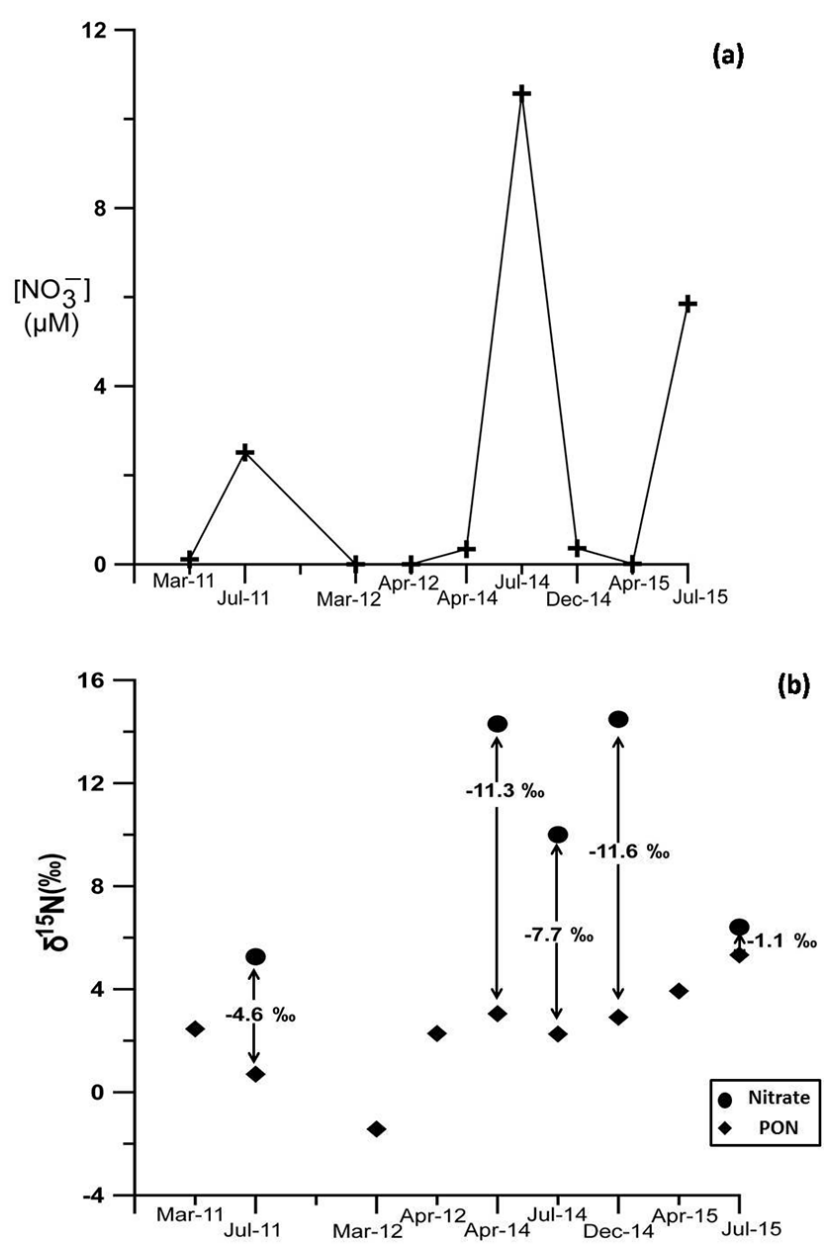

Figure 3. Time series of nitrate concentrations (a) and $\delta^{15} \mathrm{~N}$ of dissolved nitrate and POM in the epilimnion $(0-5 \mathrm{~m})(\mathbf{b})$. The isotopic differences between the dissolved and particulate species are denoted by arrows. Each data point represents a single sample.

rates in the Tillari Reservoir have yielded very low values during summer (unpublished data). Alternatively, the lower $\delta^{15} \mathrm{~N}$ values may also result from isotopically light nitrate that is produced in the hypolimnion and diffuses upward into surface waters. Another possible source of isotopically lighter $\mathrm{N}$ could be atmospheric deposition, although the magnitude of atmospheric inputs is not expected to be very large during early summer. Further work is required to understand the episodic occurrence of low $\delta^{15} \mathrm{~N}$ POM.

\subsection{Biogeochemistry of hypolimnion}

\subsubsection{Nitrification}

Stratification in the Tillari Reservoir sets in soon after the decline of the monsoon-fed inflow following which nitrate concentrations increased in oxygenated bottom waters with a concomitant decrease in ammonium concentrations, indicating the occurrence of nitrification. The nitrate concentra-

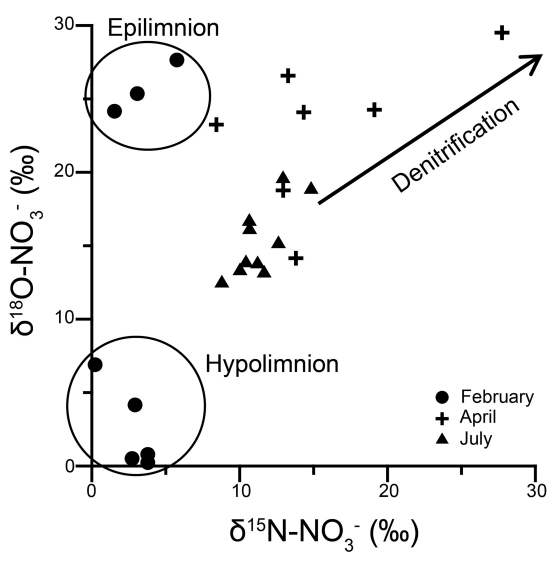

Figure 4. Nitrogen and oxygen isotopic composition of dissolved nitrate during three different periods in 2014. February represents the early or weak stratification period with two distinct clusters of epilimnetic $(0-10 \mathrm{~m})$ and hypolimnetic $(15-48 \mathrm{~m})$ samples. April is a period of intense water-column stratification and a denitrification signal is observed in the bottom waters. July is a period of monsoon holomixis when the water column has uniformly high nitrate values.

tions ranged from below detection limit in the upper $10 \mathrm{~m}$ to nearly $10 \mu \mathrm{M}$ close to the bottom. Nitrification occurs in two steps: ammonia oxidation to nitrite (performed by ammoniaoxidizing archaea and bacteria) and nitrite oxidation to nitrate (performed by nitrite-oxidizing bacteria). Ammonium, the primary $\mathrm{N}$ source, undergoes strong fractionation producing isotopically light nitrate (Delwiche and Stein, 1970; Casciotti et al., 2003). The $\delta^{15} \mathrm{~N}-\mathrm{NO}_{3}^{-}$values ranged from 2 to $10 \%$ and the $\delta^{18} \mathrm{O}-\mathrm{NO}_{3}^{-}$ranged from 5 to $8 \%$ o during this period. Nitrate accumulation due to atmospheric deposition and microbial nitrification will have distinct $\delta^{18} \mathrm{O}-\mathrm{NO}_{3}^{-}$values. This is because, while the oxygen atoms in atmospheric nitrate are derived from interactions between $\mathrm{NO}_{x}$ and $\mathrm{O}_{3}$ in the atmosphere, those in nitrate produced by nitrification come from dissolved oxygen and water (Kendall, 1998; Finlay et al., 2007). This is well reflected in the ${ }^{15} \mathrm{~N}-{ }^{18} \mathrm{O}$ scatter plot where the $\delta^{18} \mathrm{O}-\mathrm{NO}_{3}^{-}$data points from the epilimnion and hypolimnion form completely distinct clusters in February (Fig. 4). As the ammonium pool gets used up, the nitrification rate decreases accompanied by a decrease in the extent of fractionation (Feigin et al., 1974).

Ammonium, oxygen and carbon dioxide are the major substrates needed for nitrification (Christofi et al., 1981). While ammonium largely comes from the sediments, oxygen is supplied from aerated surface waters. During the early stratification period, conducive conditions exist for nitrifiers to grow within the hypolimnion. However, as the bottom waters turn increasingly more oxygen-depleted with the intensification of stratification, the "ammonium-oxygen chemocline" (Christofi et al., 1981) moves upward in the water column and the metalimnion becomes more suitable for the occurrence of nitrification. In April 2014, $\delta^{18} \mathrm{O}$ declined within 
the thermocline from $34 \%$ at $5 \mathrm{~m}$ to $14 \%$ at $20 \mathrm{~m}$ owing to nitrification. Epilimnetic nitrate isotope data are not available for 2012 due to very low nitrate concentrations. However, the $\delta^{18} \mathrm{O}$ declined from $25 \%$ at $15 \mathrm{~m}$ to $17 \%$ at $20 \mathrm{~m}$. The $\delta^{15} \mathrm{~N}$ values in both years did not show a similar decline, but this is consistent with the results of several other studies (Böttcher et al., 1990; Burns and Kendall, 2002), where the $\delta^{18} \mathrm{O}$ was found to be better suited for source and process identification than $\delta^{15} \mathrm{~N}$. It may be noted that this decoupling of $\delta^{15} \mathrm{~N}$ and $\delta^{18} \mathrm{O}$ was only observed during the peak stratification period at the thermocline.

The $\delta^{15} \mathrm{~N}$ and $\delta^{13} \mathrm{C}$ values for the POM were generally low during the nitrification period as also observed in Lake Kinneret (Hadas et al., 2009). The $\delta^{15} \mathrm{~N}$ varied from -4 to $3 \%$ while $\delta^{13} \mathrm{C}$ varied from -31 to $-29 \%$ o. Assimilation of newly nitrified $\mathrm{NO}_{3}^{-}$may be a possible contributor to POM as indicated by the low $\delta^{15} \mathrm{~N}$ values.

\subsubsection{Denitrification}

During the period of strong stratification, the water column loses oxygen below the thermocline, which apparently results in $\mathrm{N}$ loss. Along with a decrease in nitrate, there also occurs an increase in $\mathrm{NH}_{4}^{+}$concentration. Dissimilatory nitrate reduction is known to be associated with a $1: 1$ increase in $\delta^{15} \mathrm{~N}-\mathrm{NO}_{3}^{-}$and $\delta^{18} \mathrm{O}-\mathrm{NO}_{3}^{-}$(Granger et al., 2008). Linear regression of $\delta^{18} \mathrm{O}$ vs. $\delta^{15} \mathrm{~N}$ yielded slope values of 0.95 and 0.85 in 2014 and 2012, respectively. In canonical denitrification, both $\delta^{15} \mathrm{~N}-\mathrm{NO}_{3}^{-}$and $\delta^{18} \mathrm{O}-\mathrm{NO}_{3}^{-}$increase linearly. The enrichment in isotopic value is $\sim 1$ in marine systems (Casciotti et al., 2002; Sigman et al., 2005; Granger et al., 2008). However, this value is reported to be lower $(0.5-0.7)$ in freshwater systems (Lehmann et al., 2003, and references therein). The reasons for this difference are not fully understood. Also, studies in freshwater systems are sparse as compared to marine systems. In a batch of culture experiments, Granger et al. (2008) observed that nitrate-reducing enzymes play a role in altering the $\mathrm{O}$ to $\mathrm{N}$ isotopic enrichment, with periplasmic dissimilatory nitrate reductase (Nap) expressing a lower enrichment value $(\sim 0.62)$ than the membrane-bound dissimilatory nitrate reductase. Again, there is a lack of data on the isotopic expressions of these enzymes at the ecosystem level. Wenk et al. (2014) attributed the low $\mathrm{O}: \mathrm{N}$ isotopic effect of $\sim 0.89$ to chemolithoautotrophic denitrification, rather than heterotrophic denitrification, in the northern basin of Lake Lugano.

Our data from the Tillari Reservoir indicates the occurrence of denitrification in the suboxic hypolimnion under stratified conditions. However, this process is restricted to a narrow depth range of $10-20 \mathrm{~m}$, which limits the number of data points. There may be several factors responsible for the low $(<1)$ isotopic enrichment factor in the Tillari but our data are not sufficient to identify the exact cause(s).

Assuming the $\mathrm{N}$ loss was largely through denitrification, an attempt was made to compute the fractionation factor using a Rayleigh "closed-system" model (Lehmann et al., 2003). Although there have been several attempts to compute the nitrogen isotope enrichment factors in marine systems, groundwater and laboratory cultures (Table 1), similar information is relatively scarce from freshwater lakes and reservoirs.

The available information on oxygen isotope fractionation is even scarcer. The values of $\varepsilon^{15}$ and $\varepsilon^{18}$ computed by us are -8.7 and $-10.7 \%$, respectively. The $\varepsilon^{15}$ is much lower than those obtained from laboratory cultures (Olleros, 1983; Table 1) as well as open-ocean OMZs (oxygen minimum zones) (Brandes et al., 1998; Voss et al., 2001; Table 1), although it is close to the $\varepsilon^{15}$ reported from the eutrophic Lake Lugano. Factors controlling denitrification rates in aquatic systems include temperature, availability of nitrate and organic carbon, oxygen concentration and type of bacterium involved (Seitzinger, 1988; Böttcher et al., 1990, and references therein). Sedimentary denitrification is known to incur isotope effect $\left(\varepsilon^{15}\right)$ of $\sim 0 \%$ o due to almost complete exhaustion of nitrate. The dissolved nitrate concentrations in the Tillari Reservoir are quite low with the highest values being in the range of 10-12 $\mu \mathrm{M}$ (see Results). The hypolimnetic nitrate concentrations were even lower $(<5 \mu \mathrm{M})$ during periods of anoxia. Low nitrate availability and sedimentary $\mathrm{N}$ loss may exert major controls on the low $\varepsilon^{15}$ observed in the Tillari Reservoir.

Denitrification strongly discriminates among the two $\mathrm{N}$ isotopes, leaving behind ${ }^{15} \mathrm{~N}$ enriched in the residual $\mathrm{NO}_{3}^{-}$. POM produced by assimilation of this nitrate will also be enriched in ${ }^{15} \mathrm{~N}$. However, lower $\delta^{15} \mathrm{~N}$ PON at these depths implies that $\mathrm{NH}_{4}^{+}$was the preferred DIN source. For instance, observations in April 2012 showed that denitrification was active below $30 \mathrm{~m}$ and associated with ammonium build-up; there was nearly a $4 \%$ o depletion in $\delta^{15} \mathrm{~N}$ PON from $2.5 \%$ o (at $30 \mathrm{~m}$ ) to $-2.3 \%$ (at $40 \mathrm{~m}$ ).

\subsubsection{Ammonification}

The isotopic composition of ammonium should reflect that of the sedimentary organic matter being degraded. In Lake Kinneret, Israel, $\delta^{15} \mathrm{~N}-\mathrm{NH}_{4}^{+}$values in the hypolimnion during stratified conditions ranged from 12 to $17 \%$ reflecting the high $\delta^{15} \mathrm{~N}$ of the sedimentary organic matter (OM; $\delta^{15} \mathrm{~N}=10 \%$ ) (Hadas et al., 2009). In Lake Bled, northwestern Slovenia, the mean $\delta^{15} \mathrm{~N}-\mathrm{NH}_{4}^{+}$value of $3.8 \%$ was similar to that of sedimentary $\mathrm{OM}\left(\delta^{15} \mathrm{~N}=4.5 \%\right.$ ) (Bratkic et al., 2012). Likewise, the sedimentary OM in the Tillari Reservoir had a $\delta^{15} \mathrm{~N}$ of $2.96 \%$ o similar to the $\delta^{15} \mathrm{~N}-\mathrm{NH}_{4}^{+}(1.3-2.6 \%$ ), thus establishing remineralization of sedimentary $\mathrm{OM}$ as the principal $\mathrm{NH}_{4}^{+}$source.

A negative linear relationship between $\delta^{15} \mathrm{~N}$ PON and $\ln \left[\mathrm{NH}_{4}^{+}\right]$was observed (Fig. $5 \mathrm{~b}$ ), which further indicated uptake of $\mathrm{NH}_{4}^{+}$. Although this relation was mainly determined by the low $\left[\mathrm{NH}_{4}^{+}\right]$and high $\delta^{15} \mathrm{~N}$ PON observed at the top of the hypolimnion $(20 \mathrm{~m})$, it is important to include this data 
Table 1. The values of nitrogen $\left(\varepsilon^{15}\right)$ and oxygen $\left(\varepsilon^{18}\right)$ isotope effects for denitrification as reported from some natural systems as well as laboratory cultures.

\begin{tabular}{lrrl}
\hline Study area & $\varepsilon^{15}(\% \circ)$ & $\varepsilon^{18}(\% \circ)$ & Reference \\
\hline Cariaco Basin, Venezuela & -1.5 & & Thunell et al. (2004) \\
Beijiang River, China & -14.8 & -8.5 & Chen et al. (2009) \\
Boknis Eck, Baltic Sea & -18.9 & -15.8 & Dähnke and Thamdrup (2013) \\
Lake Lugano, Switzerland & -11.2 & -6.6 & Lehmann et al. (2003) \\
Groundwater & -27.6 & -18.3 & Mengis et al. (1999) \\
Denitrifier culture & -30 & -15 & Olleros (1983) \\
Denitrifier culture & -10 to -15 & & Kritee et al. (2012) \\
Open-ocean OMZs & -20 to -30 & & Brandes et al. (1998); Voss et al. (2001) \\
Shallow groundwater aquifer & -15.9 & -8 & Böttcher et al. (1990) \\
Tillari Reservoir, India & -8.73 & -10.74 & This study \\
\hline
\end{tabular}

point to highlight the rapid decline of $\delta^{15} \mathrm{~N}$ PON over a short depth range. The fractionation factor $(\varepsilon)$ calculated from the slope was $-2.4 \%$. The fractionation factor for ammonium assimilation has been estimated in several field studies (Cifuentes et al., 1988; Bratkic et al., 2012) as well as in lab cultures with different organisms (green algae, marine bacteria, etc.) (Wada and Hattori, 1978; Wada, 1980; Hoch et al., 1992). However, such studies in freshwater lakes and reservoirs are scarce. Bratkic et al. (2012) computed fractionation factors of -0.8 and $-1.4 \%$ for mean ammonium concentrations of 4.7 and $3.3 \mu \mathrm{M}$, respectively, in Lake Bled. Hoch et al. (1992) reported fractionation factor for assimilation by Vibrio harveyi, a marine bacterium, to be between -4 and $-27 \%$ for ammonium concentrations ranging from 23 to $180 \mu \mathrm{M}$. The fractionation factor is expected to approach $0 \%$ o for decreased concentrations of ammonium. For the low to moderate ammonium concentrations recorded (maximum $\sim 12 \mu \mathrm{M}$ in Fig. 5), the fractionation factor computed by us compares well with previously reported values.

\subsubsection{Sulfate reduction and evidence for chemosynthesis}

As the summer intensified and oxidized nitrogen was fully utilized, facultative bacteria apparently began to utilize sulfate as an electron acceptor as indicated by the accumulation of $\mathrm{H}_{2} \mathrm{~S}$. Mass-dependent fractionation during microbial degradation of organic matter with sulfate as an electron acceptor would enrich the residual organic matter in ${ }^{13} \mathrm{C}$ and ${ }^{15} \mathrm{~N}$. However, following the appearance of $\mathrm{H}_{2} \mathrm{~S}$, both $\delta{ }^{13} \mathrm{C}$ POC and $\delta^{15} \mathrm{~N}$ PON became more depleted. The $\delta^{15} \mathrm{~N}$ values varied between -8 and $-5 \%$ and $\delta^{13} \mathrm{C}$ values ranged from -37 to $-32 \%$ o between 30 and $40 \mathrm{~m}$ depths. The accumulation of $\mathrm{H}_{2} \mathrm{~S}$ was also accompanied by significant build-up of $\mathrm{CH}_{4}(20-150 \mu \mathrm{M})$ and $\mathrm{NH}_{4}^{+}(1-20 \mu \mathrm{M})$ (Naik et al., 2017). Increases in POC and PON contents were also observed: from 28 to $60 \mu \mathrm{M}$ for POC and from 4.7 to $8 \mu \mathrm{M}$ for PON. Bacterial assimilation of ammonium can explain the isotopically light nitrogen, but utilization of biogenic methane is
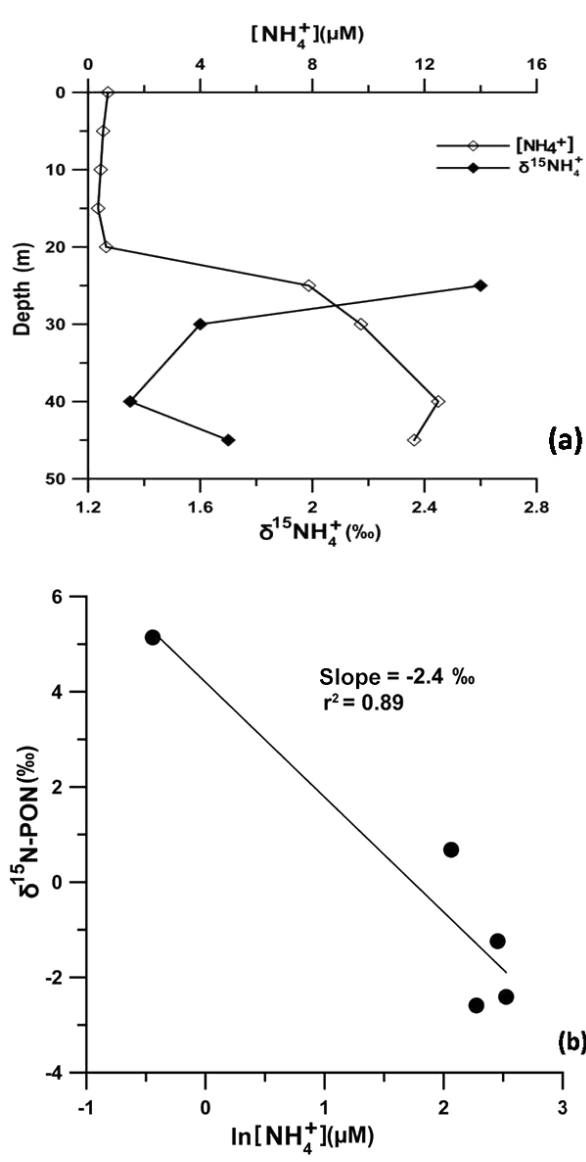

Figure 5. (a) Depth-wise variations of ammonium concentration and $\delta^{15} \mathrm{~N}-\mathrm{NH}_{4}^{+}$in May 2012. (b) Plot of $\delta^{15} \mathrm{~N}$ PON vs. $\ln \left(\mathrm{NH}_{4}^{+}\right)$. The negative linear correlation yields a fractionation factor $(\varepsilon)$ of $-2.4 \%$. Each data point represents a single sample.

known to lead to extremely low $\delta^{13} \mathrm{C}$ values (between -65 and $-50 \%$; Whiticar et al., 1986). In our study, the most depleted $\delta^{13} \mathrm{C}$ POC value of $-37.8 \%$ was associated with the highest methane concentration of $156 \mu \mathrm{M}$. Interestingly, in a study carried out in the waters of Lake Baikal in Siberia, very 

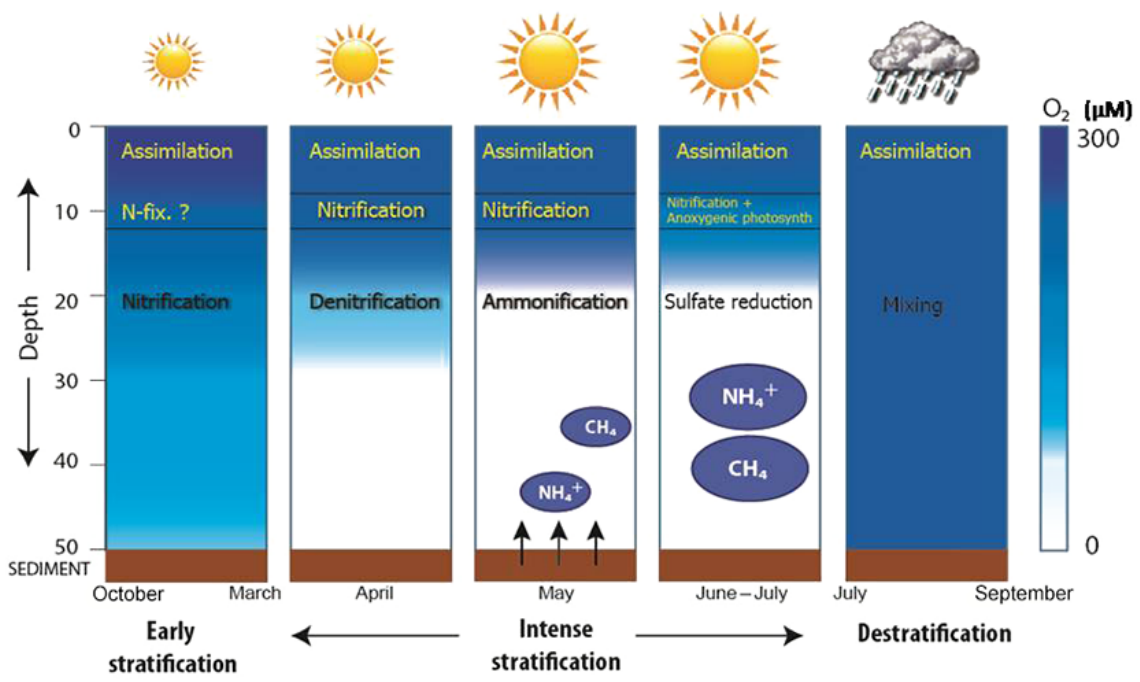

Figure 6. Schematic diagram depicting major biogeochemical processes taking place in the Tillari Reservoir over an annual cycle. This information is based on monthly sampling in the reservoir for several years (Shenoy et al., 2017).

negative $\delta^{13} \mathrm{C}$ DIC values ( -28.9 to $-35.6 \%$ ) were inferred to be derived from methane oxidation while the $\delta^{13} \mathrm{C}$ POC values ( -31.7 to $-33.5 \%$ ) were typical of lacustrine organic matter (Prokopenko and Williams, 2005). The authors explained this lack of correlation between the two $\mathrm{C}$ pools with a possible time lag between the peak methane oxidation and peak productivity. Low $\delta^{13} \mathrm{C}$ POC $(\sim-37 \%$ ) in Lake Kinneret was attributed to chemosynthetic $\mathrm{C}$ fixation using depleted $\delta^{13} \mathrm{C}$ DIC derived from methane oxidation (Hadas et al., 2009). It is important to understand the fate of methane in freshwater systems as they are believed to be significant contributors to atmospheric methane emissions (Bastviken et al., 2004). The POM isotopic data of the Tillari Reservoir provides evidence for intense microbial chemosynthesis using sulfide, ammonia and methane as energy donors.

\subsection{Monsoon mixing in the Tillari Reservoir}

The reservoir gets vertically mixed during the months of July, August and September due to a combination of lower atmospheric temperature, strong winds and an inflow of relatively cold water during the SWM. Nitrate concentrations are moderately high throughout the water column, although variable from one year to another. The mean water-column nitrate concentrations were $7.26 \pm 2.8 \mu \mathrm{M}(n=10)$ in 2011 , $9.29 \pm 0.8 \mu \mathrm{M}(n=10)$ in 2014 and $8.13 \pm 4.7 \mu \mathrm{M}(n=9)$ in 2015. The isotopic composition of nitrate also showed interannual variability. While the water column was uniformly nitrate replete in 2014 , the epilimnetic $(0-5 \mathrm{~m})$ nitrate concentrations in 2011 and 2015 were markedly lower than those at deeper depths (Fig. 7), except at the two deepest samples in 2015. This may indicate nitrate uptake by phytoplankton. However, considering its high concentration in rainwater, ammonium is expected to compete with nitrate for phy- toplankton uptake. Moreover, the $\delta^{15} \mathrm{~N}$ of nitrate in the epilimnion was lower in 2011 and 2015 than in 2014. In fact, elevated values of $\delta^{15} \mathrm{~N}-\mathrm{NO}_{3}^{-}(>8 \%$ ) occurred throughout the water column in 2014 when the nitrate concentration was also generally higher as compared to the other two years. To investigate the cause of this variability, water samples from six upstream stations along the Tillari River along with a rainwater sample at the main station were collected in 2015 . The nitrate concentrations ranged from $1.8 \mu \mathrm{M}$ at the most upstream station to $9.4 \mu \mathrm{M}$ close to our main sampling site. The ranges of $\delta^{15} \mathrm{~N}$ and $\delta^{18} \mathrm{O}$ of $\mathrm{NO}_{3}^{-}$at these stations were 0.4-6.8 and 11-27\%o, respectively. The rainwater sample had a nitrate content of $13.89 \mu \mathrm{M}(\mathrm{ammonium}=24.4 \mu \mathrm{M})$ and yielded $\delta^{15} \mathrm{~N}$ and $\delta^{18} \mathrm{O}$ values of -2.9 and $88.7 \%$, respectively. Nitrate in wet deposition is usually characterized by high $\delta^{18} \mathrm{O}(>60 \%$ ) (Kendall et al., 2007; Thibodeau et al., 2013) and low $\delta^{15} \mathrm{~N}(-10$ to $+5 \%$ ) (Heaton, 1986) values. Unfortunately, the concentration and isotopic composition of these end-members (river runoff and atmospheric deposition) do not explain the data from the Tillari, especially from the 2015. Based on the high concentration of nitrate in rainwater, it is tempting to suggest that it could be an important source, but the isotopic data show a mismatch. The $\delta^{13} \mathrm{C}$ POC values in the epilimnion decreased to nearly $-30 \%$ presumably due to a combination of lower primary productivity and inputs of organic matter through runoff. Even though the latter was not measured, POC derived from land vegetation is expected to be isotopically light. The POM data show the ingress of a nearly $30 \mathrm{~m}$ thick parcel of water from the Tillari River into the reservoir. This ingress is apparent below $5 \mathrm{~m}$ depth by a distinct $\delta^{13} \mathrm{C}$ and $\delta^{15} \mathrm{~N}$ of POM. The $\delta^{13} \mathrm{C}$ POC increases from $-30.9 \% 0( \pm 0.1 \%$ ) in the upper $5 \mathrm{~m}$ to $-25.4 \%$ o $( \pm 1 \%$ ) between 5 and $40 \mathrm{~m}$. Below $40 \mathrm{~m}$, the mean $\delta^{13} \mathrm{C}$ POC was $-26.5 \% o( \pm 1.7 \% o)$. The mean $\delta^{15} \mathrm{~N}$ 

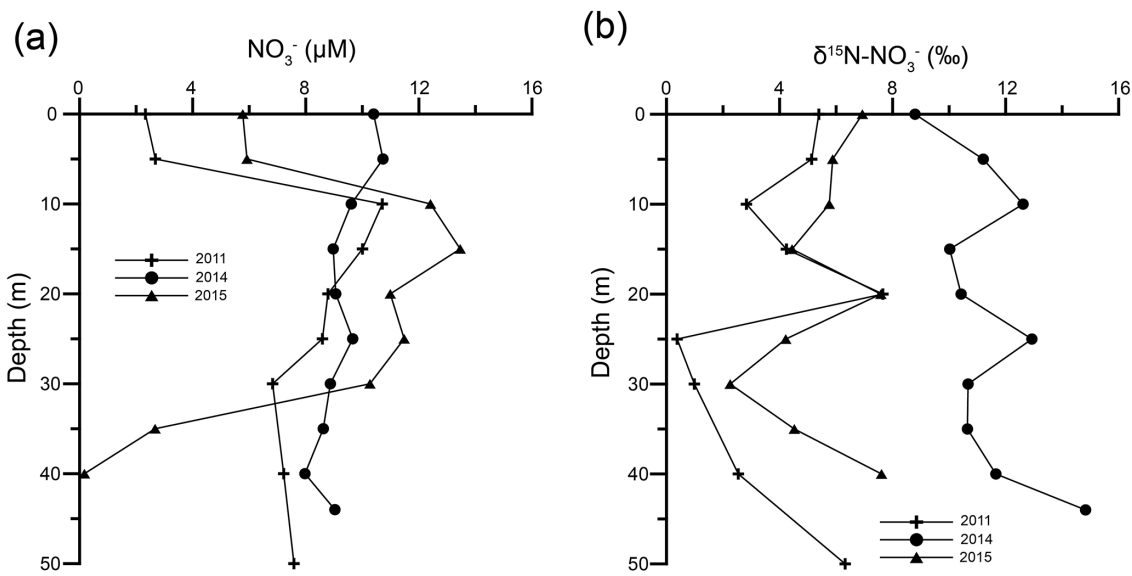

Figure 7. Vertical profiles of $\mathrm{NO}_{3}^{-}$(a) and $\delta^{15} \mathrm{~N}_{-} \mathrm{NO}_{3}^{-}$(b) during monsoon mixing in 2011, 2014 and 2015. Each profile is from one field trip during the peak SWM in a given year with each data point representing one sample.

of the intermediate water parcel was $5.97 \pm 2 \%$, as compared to $5.49 \pm 3 \%$ in the bottom waters and $3.96 \pm 2 \%$ in the upper $5 \mathrm{~m}$. The isotopic data correspond well with the ancillary chemical parameters, in that the water parcel had a distinct thermal signature (cooler by nearly $2^{\circ} \mathrm{C}$ ). It also possessed higher levels of nitrate and lower levels of DO and Chl $a$.

Thus, looking solely at the high nitrate concentrations in the water column, atmospheric wet deposition may be a major nitrate source to the water column during the monsoon season. However, this inference is based on a single measurement where the isotopic composition is also different. Moreover, the river water is also rainfed and it is not clear why its isotopic composition is much lower at the most upstream station. At the same time, the isotopic composition of POM indicates an influence of the upstream waters. Variable inputs from the atmosphere and by river runoff to the DIN pool probably account for the inter-annual variability, but more studies are needed to identify and quantify these contributions in detail.

\section{Summary and conclusions}

Using stable isotopes of nitrate, ammonium and particulate organic matter, we have been able to identify distinct watercolumn conditions and transformation processes of reactive nitrogen in the Tillari Reservoir. The reservoir gets vertically mixed during the SWM season as well as in winter; the water column remained stratified during other parts of the year. The most intense stratification occurs during summer just before the monsoon onset. The relative importance of microbial processes, such as nitrification, denitrification, ammonification and sulfate reduction in the water column, varied depending on intensity of stratification and associated DO levels in the hypolimnion. These processes produced unique isotopic signatures in the dissolved and particulate matter. Our results suggest the occurrence of microbial chemosynthesis using methane and ammonium as primary $\mathrm{C}$ and $\mathrm{N}$ sources, producing organic matter in the anoxic bottom waters that is highly depleted in ${ }^{13} \mathrm{C}$ and ${ }^{15} \mathrm{~N}$ content. The thermocline in the Tillari Reservoir has been known to harbour photoautotrophic sulfur bacteria during peak stratification periods (Kurian et al., 2012). We also found strong signatures of nitrification within this zone during summer stratification. Autochthonous production was the principal source of organic matter in the epilimnion, which was well-oxygenated at all times, although productivity was significantly lower during the monsoon period due to light-limited conditions. Nitrate was the preferred DIN source in the epilimnion. When nitrate loss occurred in the hypolimnion, the preferred DIN species switched from nitrate to ammonium. Isotopic measurement of precipitation and upstream river samples during one seasonal sampling provided some insight into sources of nitrogen, but the observed inter-annual variability could not be explained. Overall, solar intensity, water depth and redox conditions appear to be the major factors controlling biogeochemical cycling in this pristine reservoir.

\section{The Supplement related to this article is available online at doi:10.5194/bg-14-767-2017-supplement.}

Competing interests. The authors declare that they have no conflict of interest. 
Acknowledgements. We thank the Director, CSIR-NIO for providing necessary support for this work and the management body of the Tillari Reservoir for permission to carry out this study. This research was carried out as a part of INDIAS IDEA project funded by the Council of Scientific \& Industrial Research (CSIR). The authors wish to thank Mark Altabet and Laura Bristow for sharing their expertise. We thank Sugata Hazra and the School of Oceanographic Studies, Jadavpur University for their support and encouragement. Puja Satardekar is acknowledged for analyzing the nutrient samples. Sujal Bandodkar (DTP section, CSIR-NIO) is thanked for her creative inputs. P. Bardhan thanks CSIR for the award of Senior Research Fellowship. The authors are also grateful to M. V. Maya for her initial assistance in isotopic analyses and to H. Dalvi, A. Methar, J. Lobo and S. Yanamandra for their help during field work. This is NIO Contribution no. 5978.

Edited by: B. A. Pellerin

Reviewed by: two anonymous referees

\section{References}

Altabet, M. A.: Variations in nitrogen isotopic composition between sinking and suspended particles: Implications for nitrogen cycling and particle transformation in the open ocean, Deep-Sea Res., 35, 535-554, 1988.

Altabet, M. A.: Isotopic tracers of the marine nitrogen cycle, in: Marine organic matter: Chemical and biological markers, edited by: Volkman, J., The handbook of environmental chemistry, Springer-Verlag, 251-293, 2006.

Bastviken, D., Cole, J. J., Pace, M., and Tranvik, L.: Methane emissions from lakes: Dependence of lake characteristics, two regional assessments, and a global estimate, Global Biogeochem. Cy., 18, GB4009, doi:10.1029/2004GB002238, 2004.

Böttcher, J., Strebel, O., Voerkelius, S., and Schmidt, H.-L.: Using isotope fractionation of nitrate-nitrogen and nitrate-oxygen for evaluation of microbial denitrification in a sandy aquifer, J. Hydrol., 114, 413-424, doi:10.1016/0022-1694(90)90068-9, 1990.

Brandes, J. A., Devol, A. H., Yoshinari, T., Jayakumar, D. A., and Naqvi, S. W. A.: Isotopic composition of nitrate in the central Arabian Sea and eastern tropical North Pacific: A tracer for mixing and nitrogen cycles, Limnol. Oceanogr., 43, 1680-1689, doi:10.4319/lo.1998.43.7.1680, 1998.

Bratkic, A., Šturm, M., Faganeli, J., and Ogrinc, N.: Semiannual carbon and nitrogen isotope variations in the water column of Lake Bled, NW Slovenia, Biogeosciences, 9, 1-11, doi:10.5194/bg-9-1-2012, 2012.

Burns, D. A. and Kendall, C.: Analysis of ${ }^{15} \mathrm{~N}$ and ${ }^{18} \mathrm{O}$ sources in runoff at two watersheds in the Catskill Mountains of New York, Water Resour. Res., 38, 1051, doi:10.1029/2001WR000292, 2002.

Carpenter, E. J., Harvey, H. R., Fry, B., and Capone, D. G.: Biogeochemical tracers of the marine cyanobacterium Trichodesmium, Deep-Sea Res. Pt. I, 44, 27-38, 1997.

Casciotti, K. L., Sigman, D. M., Galanter Hastings, M., Bohlke, J. K., and Hilkert, A.: Measurement of the oxygen isotopic composition of nitrate in seawater and freshwater using the denitrifier method, Anal. Chem., 74, 4905-4912, 2002.
Casciotti, K. L., Sigman, D. M., and Ward, B. B.: Linking diversity and stable isotope fractionation in ammonia-oxidizing bacteria, Geomicrobiol. J., 20, 335-353, 2003.

Chen, F. J. and Jia, G. D.: Spatial and seasonal variations in $\delta^{13} \mathrm{C}$ and $\delta^{15} \mathrm{~N}$ of particulate organic matter in a damcontrolled subtropical river, River Res. Appl., 25, 1169-1176, doi:10.1002/rra.1225, 2009.

Chen, F., Jia, G., and Chen, J.: Nitrate sources and watershed denitrification inferred from dual isotopes in the Beijiang River, South China, Biogeochemistry, 94, 163-174, doi:10.1007/s10533-009-9316-x, 2009.

Chen, Z. X., Yu, L., Liu, W. G., Lam, M. H. W., Liu, G. J., and Yin, X. B.: Nitrogen and oxygen isotopic compositions of watersoluble nitrate in Taihu Lake water system, China: implication for nitrate sources and biogeochemical process, Environ Earth Sci., 1, 217-223, 2014.

Christofi, N., Preston, T., and Stewart, W. D. P.: Endogenous nitrate production in an experimental enclosure during summer stratification, Water Res., 15, 343-349, doi:10.1016/00431354(81)90039-7, 1981.

Cifuentes, L. A., Sharp, J. H., and Fogel, M. L.: Stable carbon and nitrogen isotope biogeochemistry in the Delaware Estuary, Limnol. Oceanogr., 33, 1102-1115, 1988.

Cline, J. D.: Spectrophotometric determination of hydrogen sulfide in natural waters, Limnol. Oceanogr., 14, 454-458, 1969.

Dähnke, K. and Thamdrup, B.: Nitrogen isotope dynamics and fractionation during sedimentary denitrification in Boknis Eck, Baltic Sea, Biogeosciences, 10, 3079-3088, doi:10.5194/bg-103079-2013, 2013.

Delwiche, C. C. and Stein, P. L.: Nitrogen isotope fractionation in soil and microbial reactions, Environ. Sci. Technol., 4, 929-935, 1970.

Feigin, A., Shearer, G., Kohl, D. H., and Commoner, B.: The amount and nitrogen-15 content of nitrate in soil profiles from two central Illinois fields in a corn-soybean rotation, Soil Sci. Soc. Am. Pro., 38, 465-471, 1974.

Finlay, J. C., Sterner, R. W., and Kumar, S.: Isotopic evidence for inlake production of accumulating nitrate in Lake Superior, Ecol. Appl., 17, 2323-2332, doi:10.1890/07-0245.1, 2007.

Granger, J., Sigman, D. M., Lehmann, M. F., and Tortell, P. D.: Nitrogen and oxygen isotope fractionation during dissimilatory nitrate reduction by denitrifying bacteria, Limnol. Oceanogr., 53, 2533-2545, 2008.

Grasshoff, K., Ehrhardt, M., and Kremling, K.: Methods of seawater analysis, 2nd Edn., 419 pp., Weinheim: Verlag Chemie, 1983.

Gu, B., Chapman, A. D., and Schelske, C. L.: Factors controlling seasonal variations in stable isotope composition of particulate organic matter in a soft water eutrophic lake, Limnol. Oceanogr., 51, 2837-2848, 2006.

Hadas, O., Altabet, M. A., and Agnihitori, R.: Seasonally varying nitrogen isotope biogeochemistry of particulate organic matter in lake Kinneret, Israel, Limnol. Oceanogr., 54, 75-85, 2009.

Heaton, T. H. E.: Isotopic studies of nitrogen pollution in the hydrosphere and atmosphere: A review, Chem. Geol., 59, 87-102, 1986.

Hoch, M. P., Fogel, M. L., and Kirchman, D. L.: Isotope fractionation associated with ammonium uptake by a marine bacterium, Limnol. Oceanogr., 37, 1447-1459, 1992. 
Holmes, R. M., McClelland, J. W., Sigman, D. M., Fry, B., and Peterson, B. J.: Measuring ${ }^{15} \mathrm{~N}-\mathrm{NH}_{4}^{+}$in marine, estuarine and fresh waters: an adaptation of the ammonia diffusion method for samples with low ammonium concentrations, Mar. Chem., 60, 235-243, doi:10.1016/S0304-4203(97)00099-6, 1998.

Hu, H., Bourbonnais, A., Larkum, J., Bange, H. W., and Altabet, M. A.: Nitrogen cycling in shallow low-oxygen coastal waters off Peru from nitrite and nitrate nitrogen and oxygen isotopes, Biogeosciences, 13, 1453-1468, doi:10.5194/bg-13-1453-2016, 2016.

Junet, A. de, Abril, G., Guèrin, F., Billy, I., and Wit, R. de.: A multitracers analysis of sources and transfers of particulate organic matter in a tropical reservoir (Petit Saut, French Guiana), River Res. Appl., 25, 253-271, doi:10.1002/rra.1152, 2009.

Kendall, C.: Tracing nitrogen sources and cycling in catchments, in: Isotope tracers in catchment hydrology, edited by: Kendall, C. and McDonnell, J. J., Elsevier, Amsterdam, the Netherlands, 519-576, 1998.

Kendall, C., Silva, S. R., and Kelly, V. J.: Carbon and nitrogen isotopic compositions of particulate organic matter in four large river systems across the United States, Hydrol. Process., 15, 1301-1346, doi:10.1002/hyp.216, 2001.

Kendall, C., Elliott, E. M., and Wankel, S. D.: Tracing anthropogenic inputs of nitrogen to ecosystems, Chapter 12, in: Stable Isotopes in Ecology and Environmental Science, edited by: Michener, R. H. and Lajtha, K., 2nd Edn., Blackwell Publishing, 375-449, 2007.

Kritee, K., Sigman, D. M., Granger, J., Ward, B. B., Jayakumar, A., and Deutsch, C.: Reduced isotope fractionation by denitrification under conditions relevant tothe ocean, Geochim. Cosmochim. Ac., 92, 243-259, doi:10.1016/j.gca.2012.05.020, 2012.

Kurian, S., Roy, R., Repeta, D. J., Gauns, M., Shenoy, D. M., Suresh, T., Sarkar, A., Narvenkar, G., Johnson, C. G., and Naqvi, S. W. A.: Seasonal occurrence of anoxygenic photosynthesis in Tillari and Selaulim reservoirs, Western India, Biogeosciences, 9, 2485-2495, doi:10.5194/bg-9-2485-2012, 2012.

Lehmann, M. F., Reichert, P., Bernasconi, S. M., Barbieri, A., and McKenzie, J.: Modelling nitrogen and oxygen isotope fractionation during denitrification in a lacustrine redox-transition zone, Geochim. Cosmochim. Ac., 67, 2529-2542, doi:10.1016/S00167037(03)00085-1, 2003.

Lehmann, M. F., Bernasconi, S., McKenzie, J., Barbieri, A., Simona, M., and Veronesi, M.: Seasonal variation of the $\delta^{13} \mathrm{C}$ and $\delta^{15} \mathrm{~N}$ of particulate and dissolved carbon and nitrogen in Lake Lugano: Constraints on biogeochemical cycling in a eutrophic lake, Limnol. Oceanagr., 49, 415-429, 2004.

Maya, M. V., Karapurkar, S. G., Naik, H., Roy, R., Shenoy, D. M., and Naqvi, S. W. A.: Intra-annual variability of carbon and nitrogen stable isotopes in suspended organic matter in waters of the western continental shelf of India, Biogeosciences, 8, 34413456, doi:10.5194/bg-8-3441-2011, 2011.

McIlvin, M. R. and Altabet, M. A.: Chemical conversion of nitrate and nitrite to nitrous oxide for nitrogen and oxygen isotopic analysis in freshwater and seawater, Anal. Chem., 77, 5589-5595, doi:10.1021/ac050528s, 2005.

Mengis, M., Schiff, S. L., Harris, M., English, M. C., Aravena, R., Elgood, R. J., and MacLean, A.: Multiple geochemical and isotopic approaches for assessing ground water $\mathrm{NO}_{3}^{-}$elimination in a riparian zone, Ground Water, 37, 448-457, 1999.
Naik, H., Shenoy, D. M., and Naqvi, S. W. A.: Biogeochemical cycling of nitrogen in the Tillari Reservoir, in preparation, 2017.

Narvenkar, G., Naqvi, S. W. A., Kurian, S., Shenoy, D. M., Pratihary, A. K., Naik, H., Patil, S., Sarkar, A., and Gauns, M.: Dissolved methane in Indian freshwater reservoirs, Environ. Monit. Assess., 185, 6989-6999, 2013.

Olleros, T.: Kinetische Isotopeneffekte der Arginase- und Nitratreduktase-Reaktion: Ein Beitrag zur Aufklärung der entsprechenden Reaktionsmechanismen, $\mathrm{PhD}$ dissertation, Technische Universität München-Weihenstephan, Germany, 1983.

Pang, P. C. and Nriagu, J. O.: Isotopic variations of the nitrogen in Lake Superior, Geochim. Cosmochim. Ac., 41, 811-814, doi:10.1016/0016-7037(77)90051-5, 1977.

Prokopenko, A. A. and Williams, D. F.: Depleted methane-derived carbon in waters of Lake Baikal, Siberia, Hydrobiol., 544, 279288, 2005.

Savoye, N., David, V., Morisseau, F., Etcheber, H., Abril, G., Billy, I., Charlier, K., Oggian, G., Derriennic, H., and Sautour, B.: Origin and composition of particulate organic matter in a macrotidal turbid estuary: the Gironde Estuary, France, Estuar. Coast. Shelf S., 108, 16-28, doi:10.1016/j.ecss.2011.12.005, 2012.

Seitzinger, S. P.: Denitrification in freshwater and coastal marine ecosystems: Ecological and Geochemical significance, Limnol. Oceanogr., 33, 702-724, 1988.

Shenoy, D. M., Naik, H., Kurian, S., Gauns, M., and Naqvi, S. W. A.: Impact of summer stratification and winter mixing on hydrogen sulfide production in a tropical freshwater reservoir, in preparation, 2017.

Sigman, D. M., Granger, J., DiFiore, P. J., Lehmann, M. M., Ho, R., Cane, G., and van Geen, A.: Coupled nitrogen and oxygen isotope measurements of nitrate along the eastern North Pacific margin, Global Biogeochem. Cy., 19, GB4022, doi:10.1029/2005GB002458, 2005.

Subramanya, K.: Engineering Hydrology, 4th Edn., McGraw-Hill Publishing, New Delhi, 2013.

Sukumar, R., Suresh, H. S., and Ramesh, R.: Climate change and its impact on tropical montane ecosystems in southern India, J. Biogeogr., 22, 533-536, 1995.

Thibodeau, B., Hélie, J.-F., and Lehmann, M. F.: Variations of the nitrate isotopic composition in the St. Lawrence River caused by seasonal changes in atmospheric nitrogen inputs, Biogeochemistry, 115, 287-298, 2013.

Thunell, R. C., Sigman, D. M., Muller-Karger, F., Astor, Y., and Varela, R.: Nitrogen isotope dynamics of the Cariaco Basin, Venezuela, Global Biogeochem. Cy., 18, GB3001, doi:10.1029/2003GB002185, 2004.

Voss, M., Dippner, J. W., and Montoya, J. P.: Nitrogen isotope patterns in the oxygen-deficient waters of the Eastern Tropical North Pacific Ocean, Deep-Sea Res. Pt. I, 48, 1905-1921, doi:10.1016/S0967-0637(00)00110-2, 2001.

Wada, E.: Nitrogen isotope fractionation and its significance in biogeochemical processes occuring in marine environments, in: Isotope Marine Chemistry, edited by: Goldberg, E. D., Horibe, Y., and Saruhashi, K., Uchida Rokakuho Pub. Co., Tokyo, 375-398, 1980.

Wada, E. and Hattori, A.: Nitrogen isotope effects in the assimilation of inorganic compounds by marine diatoms, Geomicrobiol. J., 1, 85-101, 1978. 
Wankel, S. D., Kendall, C., Pennington, J. T., Chavez, F. P., and Paytan, A.: Nitrification in the euphotic zone as evidenced by nitrate dual isotopic composition: Observations from Monterey Bay, California, Global Biogeochem. Cy., 21, GB2009, doi:10.1029/2006gb002723, 2007.

Wenk, C. B., Zopfi, J., Blees, J., Veronesi, M., Niemann, H., and Lehmann, M. F.: Community $\mathrm{N}$ and $\mathrm{O}$ isotope fractionation by sulfide-dependent denitrification and anammox in a stratified lacustrine water column, Geochim. Cosmochim. Ac., 125, 551$563,2014$.
Whiticar, M. J., Faber, E., and Schoell, M.: Biogenic methane formation in marine and freshwater environments: $\mathrm{CO}_{2}$ reduction vs. acetate fermentation-isotope evidence, Geochim. Cosmochim. Ac., 50, 693-709, 1986. 